\title{
PELATIHAN BATIK TEKNIK ECOPRINT DALAM PEMBUATAN AKSESORI FASHION KHAS KABUPATEN MALANG
}

\author{
Arinta Rezty Wijayaningputri ${ }^{1}$, Belinda Dewi Regina ${ }^{2}$, Yohana Puspitasari Wardoyo ${ }^{3}$ \\ ${ }^{1)}$ Program Studi PGSD, Fakultas Keguruan dan Ilmu Pendidikan, Universitas Muhammadiyah Malang \\ ${ }^{2)}$ Program Studi PGSD, Fakultas Keguruan dan Ilmu Pendidikan, Universitas Muhammadiyah Malang \\ ${ }^{3)}$ Program Studi Ilmu Hukum, Fakultas Hukum, Universitas Muhammadiyah Malang \\ e-mail: arinta@umm.ac.id ${ }^{1}$, belindadewi@umm.ac.id ${ }^{2}$, yohanawardoyo@umm.ac.id ${ }^{3}$
}

\begin{abstract}
Abstrak
Dalam pelatihan Batik ecoprint tahun ini, sasaran utama adalah pendidik SDM 8 DAU di Kabupaten Malang. Mereka merupakan pendidik hebat dalam melestarikan budaya setempat khususnya Malang serta sebagai modal dalam berwirausaha. Hal ini dimaksudkan untuk mengajarkan kepada anak didiknya mempersiapkan mereka untuk lebih kreatif dan diharapkan pendidik mampu menciptakan kemandirian usaha dengan mendirikan unit usaha kecil. Batik ecoprint sendiri merupakan pembuatan batik berbahan dasar alam seperti daun-daunan. Batik ecoprint memiliki banyak kegunaan yaitu tidak mencemari lingkungan serta melatih kepekaan warna dalam pembuatannya. Selain hal diatas, kurangnya pengetahuan tentang HKI terkait motif teknik ecoprint yang dihasilkan bapak dan ibu pendidik. Oleh karena itu, tim pengabdian masyarakat UMM memberikan pelatihan pembuatan batik Ecoprint sekaligus melakukan pendampingan pendaftaran Hak Kekayaan Atas Intelektual atas motif Batik yang dihasilkan melalui Dirjen HAKI (direktorat Jenderal Hak Kekayaan Atas Intelektual) sebagai bukti kepatuhan terhadap hukum dan bentuk perlindungan hukum terhadap karya yang dihasilkan. Metode yang digunakan yaitu pelatihan dengan lima tahap dan didalamnya terdapat metode pembuatan batik Ecoprint serta metode pembuatan produk. Adapun motif yang digunakan pada batik tersebut terdiri dari berbagai jenis daun-daunan yang menyerupai benda-benda yang bias dijadikan benda dengan ciri khas Kabupaten Malang serta bisa digunakan sebagai motif Batik teknik Ecoprint. Melalui pelatihan dan pendampingan tersebut diharapkan dapat menumbuhkan jiwa wirausaha Bapak Ibu SD Muhammadiyah 8 DAU, sehingga Malang akan dipenuhi batik ecoprint hasil produksi sendiri yang sudah dihasilkan.
\end{abstract}

Kata kunci: Pelatihan, Teknik Batik Ecoprint, Aksesori

\begin{abstract}
In this year's ecoprint Batik training, the main target is DAU 8 HR educators in Malang Regency. They are great educators in preserving local culture, especially Malang as well as capital in entrepreneurship. This teaches to teach their students to prepare them to be more creative and it is hoped that educators will be able to create business independence by creating small business units. Ecoprint batik itself is a natural-based batik making such as leaves. Ecoprint batik has many uses, namely it does not pollute the environment and trains color sensitivity in its manufacture. Apart from the above, there is a lack of knowledge about Intellectual Property Rights related to the ecoprint technique motifs produced by the educators. Therefore, the UMM community service team provided training in making Ecoprint batik as well as assisting the registration of Intellectual Property Rights for Batik motifs produced through the Directorate General of Intellectual Property Rights (Directorate General of Intellectual Property Rights) as evidence of the law and a form of legal protection for the work produced. The method used is training with five stages in which there is an Ecoprint batik making method and a product manufacturing method. The motifs used in the batik consist of various types of leaves that discuss objects that can be used as objects with the characteristics of Malang Regency and can be used as batik motifs with Ecoprint techniques. Through this training and mentoring, it is hoped that it can foster an entrepreneurial spirit for the teachers of SD Muhammadiyah 8 DAU, so that Malang will fulfill its own ecoprint batik produced.
\end{abstract}

Keywords: Training, Ecoprint Batik Technique, Accessories 


\section{PENDAHULUAN}

Secara geografis SD Muhammadiyah 8 DAU terletak dipinggiran kota yang dikelilingi oleh kawasan hutan, namun belum sepenuhnya memanfaatkan hutan tersebut untuk mendukung pembelajaran. Bahan baku banyak tersedia di wilayah sekitar SD Muhammadiyah 8 DAU, namun siswa tidak memiliki keterampilan untuk mengolah bahan baku tersebut untuk dimanfaatkan menjadi sebuah produk souvenir yang layak jual. Menurut (Saptutyningsih, 2019) mengatakan nahwa di Kabupaten Malang, barang-barang yang sering ditemui yaitu miniatur, kaos bergambar candi, topeng maupun kostum dan tentunya dengan harga yang tidak murah. Walaupun ada topeng namun bukan souvenir, oleh sebab itu pengabdi berkeinginan untuk membuat pelatihan batik sebagai suvenir khas Kabupaten Malang. Untuk melestarikan budaya Batik, sehingga tim pengabdian ingin mengembangkan batik melalui sekolah-sekolah di daerah sekitar Kabupaten Malang.

Berdasarkan hasil observasi dengan ibu kepala sekolah SD Muhammadiyah 8 DAU, dimana sekolah tersebut terletak di Kabupaten Malang dengan banyak sekali ditemukan daun-daun sebagai bahan dalam pembuatan ecoprint. Akan tetapi sama sekali belum pernah dimanfaatkan daundaunan tersebut sebagai media pembelajaran. Oleh karena itu, tim pengabdi berkeinginan untuk melakukan pengabdian di SDM 8 DAU dengan pembuatan batik berbahan ecoprint yaitu berasal dari daun-daunan. Menurut (Pressinawangi, 2014) mengatakan bahwa batik ecoprint sendiri merupakan pembuatan batik berbahan dasar alam seperti daun-daunan. Penciptaan ecoprint juga memiliki promosi sebagai aset wisata. Selain itu, perlu adanya untuk lebih aktif di dalam melestarikan budaya daerah mereka melalui pembuatan batik ecoprint ini. Batik ecoprint memiliki banyak kegunaan yaitu tidak mencemari lingkungan serta melatih kepekaan warna bagi bapak dan ibu pendidik.

Selain hal diatas, kurangnya pengetahuan tentang Hak Kekayaan Intelektual terkait motif teknik ecoprint yang dihasilkan bapak dan ibu pendidik. Sehingga tim pengabdi juga berkeinginan untuk melakukan pendampingan pendaftaran Hak kekayaan Intelektual kepada bapak ibu pendidik di SDM 8 DAU. Selain itu, permasalahan yang didapati adalah belum ada pelatihan-pelatihan pembuatan suvenir sebelumnya oleh pemerintah maupun komunitas yang mengeksplorasi budaya di lingkungan sekitar khususnya batik ecoprint yang sebenarnya mempunyai potensi yang sangat besar untuk dimanfaatkan para siswa dalam menghadapi Industri 4.0 serta kurangnya pengetahuan tentang Hak Kekayaan Intelektual terkait motif teknik ecoprint yang dihasilkan.

Sehingga tim pengabdian mengangkat judul yaitu "Pelatihan Pembuatan Suvenir Aksesori Fashion Khas Kabupaten Malang Dengan Teknik Batik Ecoprint Bagi Generasi Muda Sebagai Modal Kemampuan Kewirausahaan Dan Promosi Kota Wisata”. Adapun tujuan dilakukan kegiatan pengabdian melalui SD ini adalah agar: 1) Menghasilkan suatu kreatifitas dalam kegiatan pelatihan; 2) Menghasilkan para pendidik yang dapat menciptakan lapangan pekerjaan melalui pendirian unit usaha kecil dan kemandirian usaha selain di bidang pendidikan, serta 3) menjadikan para bapak ibu pendidik ikut andil dalam melestarikan budaya di daerahnya yaitu melalui pembuatan batik ecoprint melaui bisnis atau usaha.

Tujuan dalam pengabdian ini yaitu melakukan pendampingan pendaftaran Hak kekayaan Intelektual kepada bapak ibu pendidik di SDM 8 DAU.

\section{METODE}

Pelatihan Batik teknik ecoprint dalam pembuatan aksesori fashion menggunakan metode

Tahap I : Persiapan, melakukan observasi dan wawancara dengan Tim dan Mitra yaitu kepala Sekolah SMA Negeri 1 Balong Ponorogo untuk menentukan waktu dan tempat kegiatan yang akan dilaksanakan serta kesepakatan lain mengenai prosedur kerja serta tahapan-tahapan kegiatan.

Tahap II : Pelaksanaan kegiatan penyuluhan tentang Hak Cipta Batik, tata cara pendaftaran serta pelatihan pembuatan batik Ecoprint kepada siswa-siswi kelas XI IPA 1 SMAN 1 Balong Ponorogo.

Tahap III : Pelaksanaan kegiatan pelatihan pembuatan batik Ecoprint dengan siswa-siswi kelas XI IPA 1 SMAN 1 Balong Ponorogo.

Tahap IV : Pelatihan pembuatan suvenir berbahan batik ecoprint.

Tahap V : Pendampingan pendaftaran Hak Cipta batik ecoprint khas Kabupaten Ponorogo 
Sedangkan untuk Proses Pembuatan Batik Ecoprint adalah sebagai berikut:

a. Pembuatan Ecoprint sangat tergantung pada ketersediaan bahan alami yang digunakan sebagai bahan baku utama ecoprint. Bahan baku utama pembuatan ecoprint adalah berbagai jenis daun-daunan yang tersedia di sekitarnya.

b. Alat yang digunakan untuk membuat batik Ecoprint, kain berjenis primisima, cairan tawas, tunjung, daun yang masih fresh, plastik meteran, tali rafia, batu kecil, cairan TRO, dan kain untuk mengelap daun.

c. Langkah awal yang harus dilakukan adalah membasahi daun dengan cairan tawas memakai kaos tangan. Seluruh permukaan daun harus basah sampai merata di kedua sisinya.

d. Apabila kedua sisi daun sudah basah secara merata, maka langkah selanjutnya mengelap dengan kain agar tidak terlalu basah saat diletakkan di atas kain primisima nantinya.

e. Langkah selanjutnya adalah menggelar plastik untuk melapisi kain yang sudah dibilas cairan TRO sebelumnya. Setelah plastik digelar, maka terlebih dahulu memasang kain tersebut di atasnya. Daun-daun tersebut diletakkan di tengah bagian kain. Apabila daun telah tertata rapi, maka kain dibagi dilipat menjadi dua sama besar dan dilapisi plastik kembali.

f. Kain yang sudah dilipat dua dan dilapisi plastik kembali dilipat menjadi 4 bagian sama besar lalu digulung dengan bantuan kayu bulat lalu ditali dengan menggunakan tali rafia.

g. Apabila gulungan kain sudah diikat menggunakan rafia dengan merata dan ketat, kemudian didiamkan beberapa menit.

h. Masukkan kain yang sudah digulung dan diikat tersebut kedalam dandang dan didiamkan selama 1 jam.

i. Setelah beberapa menit kemudian, kain gulungan dikeluarkan dari dandang, gulungan kain yang terdapat ikatan dari tali raffia dilepas. Apabila semua rafia telah lepas semua, maka kain digelar dan peserta diminta untuk mengambil daun-daun dari kainnya.

j. Setelah daun diambil semua dari kain, kain dicuci bersih menggunakan air yang langsung mengalir dari kran dan di keringkan dengan cara diangin-anginkan.

\section{HASIL DAN PEMBAHASAN}

Pengabdian masyarakat yang telah dilakukan di SD Muhammadiyah 8 DAU Malang memiliki beberapa tahapan sebagai berikut:

\section{Tahapan Persiapan}

Melakukan koordinasi antara tim pengabdi dan mitra untuk menentukan tempat dan waktu pelaksanaan mengenai prosedur beserta tahapan-tahapan kegiatan. Koordinasi dilakukan dengan menandatangai kesepaktan antara Kepal SD Muhammadiyah 8 DAU dan tim pengabdi.

\section{Tahapan Pemaparan Materi}

Kegiatan memberikan materi terkait pembuatan batik ecoprint yaitu cara pembuatan batik dengan teknik ecoprint yang memanfaatkan daun-daunan dari berbagai macam tumbuhan yang ada di sekitar SD Muhammadiyah 8 DAU.

\section{Tahap Pelaksanaan}

Pelatihan pembuatan batik dengan teknik ecoprint dilaksanakan dengan tahap awal yang harus dilakukan yaitu membasahi daun yang akan digunakan sebagai motif menggunakan cairan tawas sampai seluruh permukaan daunnya basah. Setelah itu, daun di lap supaya tidak terlalu basah saat diletakkan kain batik.

Selanjutnya yaitu menggelar plastik besar yang di atasnya diletakkan kain dipakai untuk melapisi kain batik yang telah ditempeli daun-daunan yang sudah dibilas cairan TRO. Daundaunan tadi diletakkan di bagian tengah kain dengan rapi. Kemudian kain dibagi serta dilipat menjadi ukuran yang sama besar dan dilapisi dengan plastik. Kemudian dilipat, digulung, dan ditali menggunkan tali rafia. Setelah itu kain tersebut dikukus selama satu jam. Selanjutnya didiamkan beberapa menit, kemudian tali dilepas dan kain digelar lalu daun yang menempel pada kain diambil dari kain. Setelah itu, kain dicuci menggunakan air bersih mengalir. Setelah bersih, kain dikeringkan.

Kegiatan pelatihan diakhiri dengan melakukan evaluasi kegiatan dengan observasi dan wawancara kepada seluruh peserta. Berdasarkan hasil observasi dan wawancara yang telah dilakukan, seluruh peserta mampu mengikuti semua langkah-langkah kegiatan dengan baik. 
Selain itu, peserta mengakui lebih memahami tentang batik teknik ecoprint dan lebih terampil dalam proses produksi.

\section{Tahap Pembuatan Goodie Bag Teknik Ecoprint}

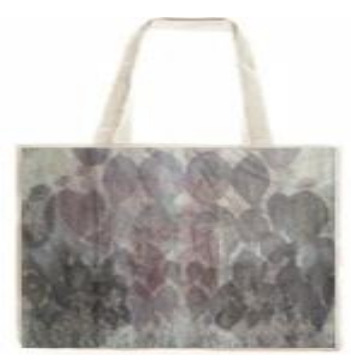

Gambar 1 Goodie Bag

Langkah-langkah pembuatan goodie bag batik ecoprint motif topeng panji diawali dengan mengukur kain batik primisima yang akan dipakai membuat goodie bag yang sudah bermotif ecoprint. Lalu membuat pola garis selebar $3 \mathrm{~cm}$ dengan penggaris pada kain tersebut supaya lurus dan rapi. Setelah itu, mengunting kain secara memanjang untuk pola dasar membuat goodie bag. Setelah digunting, pola diberi lem supaya tidak berubah posisi dan terekat kuat. Lipat kain tersebut. Rapikan pinggir-pinggir kain yang tidak diperlukan dengan cara dipotong. Siapkan tali yang kemudian disisipkan pada bagian dalam untuk menjadi pegangan goodie bag. Lalu diberi lem supaya merekat kuat pada ujung-ujung goodie bag. Langkah terakhir, diberi kancing pengait supaya goodie bag dapat dibuka dan ditutup.

\section{Tahap Pembuatan Kalung Batik Teknik Ecoprint}

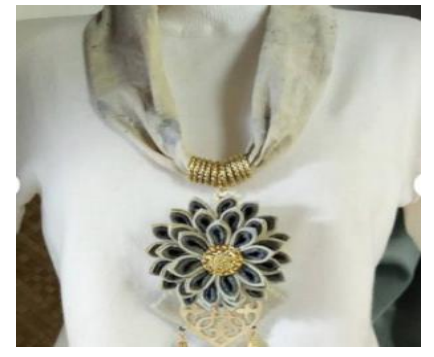

Gambar 2 Kalung Batik

Menyiapkan kain dengan motif batik ecoprint, gunting, jarum jahit, benang, lem tembak, dan kawat tembaga dengan menggunakan ukuran $2 \mathrm{~mm}$. Langkah pertama, mengunting kain batik ecoprint dengan ukuran lebar $3 \mathrm{~cm}$ dan panjang yang disesuaikan kebutuhan. Jahit kain batik bermotif pada bagian tengah sehingga membentuk sebuah selang. Seluruh yang ada pada bagian gelang diberi lem dan seluruh bagian gelang ditutup menggunakan kain yang sudah bermotif tersebut, lalu dimulai dari kedua ujung-ujung pada bagian kain batik dan hanya menyisakan sedikit bagian tengah sebagai gantungan kalung. Menjahit kembali di bagian sambungan yang terdapat di antara kalung dengan gelang. Beri sebuah hiasan dari kawat yang terbuat dari tembaga di bagian tengah gelang. Diamkan selama 10 menit sampai lem mengering kemudian kalung siap digunakan.

\section{SIMPULAN}

Kegiatan pelatihan batik teknik ecoprint dalam pembuatan aksesori fashion khas kabupaten malang sebagai modal kemampuan kewirausahaan dan promosi kota wisata menghasilkan suatu kreatifitas dalam kegiatan pelatihan. Kreatifitas yang telah dihasilkan seperti kalung batik dan goodie bag bisa dijual dengan harga yang terjangkau. Melalui hal tersebut, peserta dapat menciptakan lapangan pekerjaan melalui pendirian unit usaha kecil dan kemandirian usaha selain di bidang pendidikan. Selain itu, kegiatan pelatihan yang telah dilakukan menjadikan para bapak ibu pendidik ikut andil dalam melestarikan budaya di daerahnya yaitu melalui pembuatan batik ecoprint melaui bisnis atau usaha. 


\section{SARAN}

Perlu ada pendampingan pendaftaran Hak Cipta bagi guru yang memiliki Karya Cipta bagi guru yang memiliki karya/ ciptaan sebagaimana diatur dalam pasal 40 Undang-Undang Nomor 28 Tahun 2014 Tentang Hak Cipta.

\section{UCAPAN TERIMA KASIH}

Terimakasih kepada Kepala SD Muhammadiyah 8 DAU yang telah bersedia menyediakan tempat dalam pelatihan dan berkenan menjalin kerjasama dengan tim pengabdi. Terimakasih kepada Direktorat Penelitian dan Pengabdian Masyarakat (DPPM) Universitas Muhammadiyah Malang (UMM) yang telah memfasilitasi kegiatan pengabdian masyarakat sehingga terselenggara dengan lancar.

\section{DAFTAR PUSTAKA}

Monika, (2017) "Pelatihan Teknik Ikat Celup Pada T-Shirt Bagi Siswa Di Smalb-B Karya Mulia Surabaya, Jurnal Lentera. "vol. 06, pp. 52-56

R. N. Pressinawangi and M. S. Dr.Dian Widiawati, (2017) "Eksplorasi Teknik Ecoprint Dengan Menggunakan Limbah Besi Dan Pewarna Alami Untuk Produk Fashion," J. Tingkat Sarj. Bid. Senirupa dan Desain, vol. 3 no.1, no. 2008, pp. 1-7.

Saptutyningsih, Endah dan Wardani, Dyah Titis Kusuma. (2019). Pemanfaatan Bahan Alami Untuk Pengembangan Produk Ecoprint Di Dukuh Iv Cerme, Panjatan, Kabupaten Kulonprogo. WARTA LPM. Vol. 22, No. 2 